\title{
ECHENEIS REMORA.
}

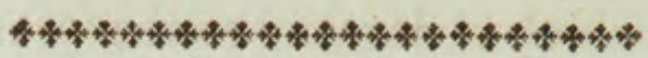

Character Genericus.

Caput supra planum, marginatum, transverse sulcato-serratum.

CHARACTER SPECIFICUS, E⿱ $\underbrace{\circ}$.

ECHENEIS cauda bifurca, striis capitis octodecim.

Lin. Syst. Nat. p. 447.

Thoracici.

ECHENEIS cauda bifurca.

Gronov. zooph. p. 75.

REMORA.

Rondel. Willught. \&c.

Insignit hoc genus capitis area quasi plana et ovata, dissepimentis plurimis transversim divisa, qua a parte adjungere se solet Echeneis imo aut lateribus navium, nec non ipsis etiam piscibus majoribus. Auxit hoc in miraculum veterum superstitio, creditumque olim est posse illam navim pleno cursu volantem de subito impedire. Huic ábsurdissimæ opinioni ansam dedisse facile crediderim parvulam quandam primavarum gentium scapham plurimis hisce piscibus 
piscibus simul adhærentibus paulisper remoratam et in latus deflexam; et rumorem in vulgus sparsum a veris initiis crevisse tandem, ut fieri plerumque solet, in ridiculas fabulas; quasi ingenita esset ipsi pisci naturalis quædam vis qua navigiis ad libitum moræ posset esse et impedimento.

Innascitur Echeneis Remora in mari Mediterraneo et Atlantico, longa, ut plurimum, quindecim uncias. 


\section{FORK-TAILED REMORA.}

\section{-}

GENERIC CHARACTER.

Head flattened at the top into an oval shield marked by numerous transverse divisions.

\section{SPECIFIC CHARACTER, छC.}

REMORA with forked tail and about eighteen divisions on the shield.

The REMORA or Pilot-Fish,

The Sucking-Fish.

This highly singular genus is at once distinguished by the uncommon appearance of the head, which is formed on the upper part into a flat, oval space, divided by numerous transverse dissepiments: by this part the animal adheres at pleasure either to the bottom or sides of vessels, or even to several of the larger fishes themselves. The popular superstition of the ancients magnified this into a kind of miraculous power in the animal, which was supposed to be able to stop a ship in full sail by adhering to it. This idea, absurd as it is, might yet have originated in truth; nor can it be thought improbable that 
3

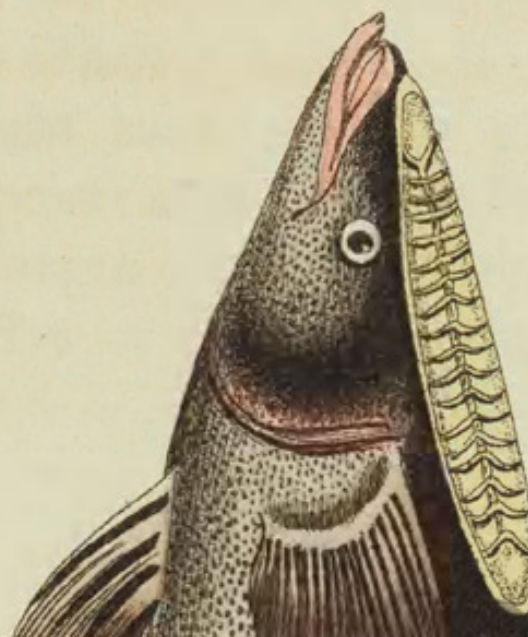

(a) 3

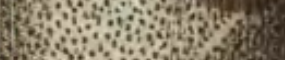

H.

* W

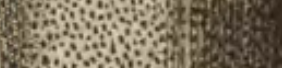

400402

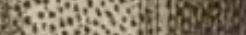

rato

6ristos

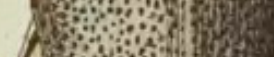

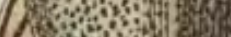

3.w.

ping

ain 6

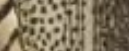

x.

(4) 15

ass.5.

애요

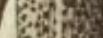

,

8
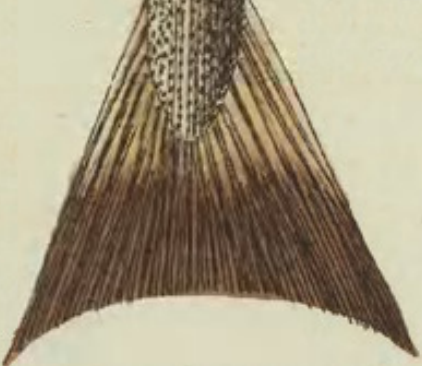

some small canoe, in the earlier ages of mankind, might in some degree have been impeded in its progress, or made to incline unequally by several of these fishes adhering to one side; and the tale, once related, might have gradually grown into the exaggerated power afterwards ascribed to the animal. The usual length of this fish is about fifteen inches: it is a native of the Mediterranean and Atlantic seas. 


\section{$2 \mathrm{BHL}$ Biodiversity Heritage Library}

Shaw, George. 1802. "The Fork-Tailed Remora, Echeneis remora [PI. 511]." The Naturalist's Miscellany 13(CLII), https://doi.org/10.5962/p.310957.

View This Item Online: https://www.biodiversitylibrary.org/item/281546

DOI: https://doi.org/10.5962/p.310957

Permalink: https://www.biodiversitylibrary.org/partpdf/310957

\section{Holding Institution}

Museums Victoria

\section{Sponsored by}

Atlas of Living Australia

\section{Copyright \& Reuse}

Copyright Status: Public domain. The BHL considers that this work is no longer under copyright protection.

This document was created from content at the Biodiversity Heritage Library, the world's largest open access digital library for biodiversity literature and archives. Visit BHL at https://www.biodiversitylibrary.org. 